\title{
Decision-making Power and Social Status of Women in Indian Society
}

\section{Shweta Mehta}

Asst. Professor of Sociology, Mata Gujri Khalsa College, Sri Ganganagar, Rajasthan, India

Corresponding author: shweta.dhruvi@gmail.com

Received: 05 Jan., 2020

Revised: 24 Feb., 2020

Accepted: 27 March, 2020

\begin{abstract}
'Women' the most beautiful creation on the earth. We can feel her divinity in form of a mother. We can feel her dedication in form of a wife. Women Empowerment refers to the creation of an environment for women where they can make decision of their own for their personal benefits as well as for the society. It also refers to increasing and improving the social, political, economic and legal strength of the women, to ensure equal right to women, and to make them confident enough to claim their rights, such as :

1. To have complete control of their life, both within and outside of their home and workplace.

2. Have equal rights to participate in social, religious and public activities.

3. To have equal social status in the society.

4. To get equal opportunities for education.

5. To get safe and comfortable working environment.

Thus, making the right decision not only gives us peace, but also save time and in modern India, women have held high officies including that of the President, Prime Minister, Speaker of the Lok Sabha etc. but the safe and comfortable environment for the women is a major issue in India. If women Empowerment to aware the all urban and rural women to protect themselves then we can call it Entire Women Empowerment in India. And every woman has own power and social status.
\end{abstract}

Keywords : Divinity, Decision-making Power, Legal Strength, Ensure, Safe and Comfortable Environment, Major Issue, Power, Social Status, Women Empowerment. 
'Women' the most beautiful creation on the earth. We can feel her passion in form of beloved. We can feel her divinity in form of a mother. We can feel her dedication in form of a wife. We can feel her warmth in form of a friend. We can feel her care in form of a sister. Her heart is so tender, yet she is so tough too. She is a woman. Women Empowerment refers to the creation of an environment for women where they can make decisions of their own for their personal benefits as well as for the society. Empowerment is meant that give power or authority to someone. Women are important to the family as a mother as well in a society. Women empowerment is giving legitimate power or authority to perform the tasks. If women empowered they would be able to participate in the planning and decision making tasks and contribute to the development programmes and activities individually. This study focuses on women empowerment through decision making authority and social status of women in Indian society.

The role and behavour of women in the society is determined by our social structure, cultural norms, value, system and social expectations etc. to great extent. Norms and standards of our society do not change at the same pace as changes take place due to technological advancement, urbanization, cost and standard of living, growth in population, industerialization and globalization. Education has become a tool and also an agent of social change promoting new knowledge, new values and new ways of improving human conditions. Through education, one is expected to become a dutiful, responsible citizen of the society. A person can be shaped in thinking, behaviour and interaction in the lime with expectation of the society through undergoing the process of education.

Empowerment refers to the process of gaining control-over self, over resources and over decision making. Empowerment in education implies (1) promoting self-recognisation, a positive selfimage and self-actualisation (2) stimulating critical thinking (3) deepening understanding of the genered structure of power, including gender (4) developing the ability to analyse the options available and to facilitate the possibility to making informed choices. Women empowerment in society and family are closely linked to decision-making influence. Decision making has been measured in terms of participation of woman in household responsibilities. And education plays an important role and influences decision making of women which is an important indicator of empowerment of women.

Its increasing and improving the social, economic, political and legal strength of the women, to ensure equal-right to women and to make them confident. Lake of decision making skills makes one indecisive and fills life with uncertainity which is a huge drain on our faculties. Thus, making the right decision not only gives us peace but also save time.

The status of women has been subject to many great changes over the past few millennia. In modern India, women have held high officies including that of the President, Prime Minister, Speaker of the Lok Sabha, Chief Minister and Governors. 
Kiran Bedi was the first woman to join the Indian Police Service in 1975.

Mrs. Pratibha Patil becomes the first woman President of India from 2007 to 2012.

Despite its all type of achievements, the safe and comfortable environment for the women is a major issue in India today. If woman empowerment to aware and educate the all urban and rural women to protect themselves then we can call it the actual entire Women Empowerment in India. And every woman has own power and social status.

\section{REVIEW OF LITERATURE}

Sharma, Rao and Sharma (2013) research stated that men dominated in majority of the farm decisions in rural families. Decisions related to buying and selling of land, machines and other agricultural implements, improvements of harvest and livestock management were mainly taken by head of the family or husbands.

Gogdand and Hembade (2014) findings clearly showed that no women make decisions without the permission of their husband for selling the animals. For milk consumption at home a whole decision is taken by the husband therefore no women make their own decisions.

According to P.V. Sumitha (2016) women strengthening is a worldwide issue attracting the consideration of specialist. Strengthening is a term widely utilised as a part of the setting of women who are equal partners being developed of the general public and the country.

According to Gopal Krishna (2017) In the previous decade, women were compelled to participate in any social exercises and not considered piece of any basic leadership process in the family. The states of women in provincial and remote zones were still more terrible. In any case, with the evolving times, women are engaged with wage producing exercise.

According to Asha Begum (2018) In spite of the fact that women constitute half of the aggregate populace of the world, their social monetary and political status is lower than that of men and they are subjected to the oppression and abuse of a specific request for a considerable length of time and accepted even today.

\section{Objective of this Study}

1. Freely live their life with a sense of self-worth, respect and dignity.

2. To have complete control of their life, both within and outside of their home and workplace.

3. To make their own choices and decisions.

4. Have equal rights to participate in social, religions and public activities.

5. To have equal social status in the society.

6. To have equal rights for social and economic justice. 
7. Determine financial and economic choice.

8. To get equal opportunity for education.

9. To get equal employment opportunity without any gender bias.

10. To get safe and comfortable working environment.

\section{Methodology}

In this study to select the category of women by Stratified Ramdom Sampling Methods And the data collects with the help of Validated Interview Schedule and Group Interview Method. The data have been collected from the 200 respondents by interview method through detailed questionnaire. The data analyzed by using statistical package for social sciences for drawing appropriate conclusion.

\section{Conclusion}

To conclude, it appears that women in the study area do not enjoy a high degree of autonomy in decision making in the family in spite of their significant contribution to economic activities. Only in purely domestic matters like decoration of house, purchase of domestic goods, making of chulla and all, marriage of children etc. Women are given freedom to take their own decisions. But in matters related to children's education and occupation and money related matters, they enjoy limited freedom. The movement of women outside home is also restricted. Thus, the patriarchic form of decision making and dominance over women still continue in the study area. These attitudes have to undergo a change before women are able to fully feel the autonomy as an individual. Education and improvement in their economic independence will help in increasing women's involvement in decision making in family.

The status of women in complex society like India is not uniform. As of the late, the conventional role of women have experienced a few changes because of financial needs and a few endeavours were made to convey perceivability and standard women's commitment to the general development and improvement of society. This paper research whether the women's in India are having same status and rights as we are asserting in regards to equality, education, health, labour, employment, marriage and family life. Race and Gender related, Religion and culture and so on. The present examination is indentified with status of women in Indian Society from antiquated days till toda. It gives significance on the situation of women in different fields like family life, social life and work circumstances. It features on female foeticide, low education level of women, women's low nourshing status, women's role in basic leadership, their situation according to Indian vonvention and so on. This paper additionally gives accentuation on number of women in all out workforce, torment of them by men in family life, social life and in different fields where they are members. In conclusion, it finishes up on significance of women and role of society for the liberation of women from 
male commanded society and their persecution and concealment. Actually men of rural areas and small cities have same thinking for the women that they are still pressurized by men. But in urban areas women have many rights and many improvements in their social status. Despite the sexual harrassment at workplace is a universal problem in the world whether it be a developed nation or a developing nation and underdeveloped nation, atrocities and cruelties against women is common everywhere.

\section{Suggestions}

Sexual harrasment is a serious problem in the workplace and it has become one of those issues that receive a lot of negative attention. The protection of women in India is the first need. If women cannot enjoy security in life then they are not empowered.
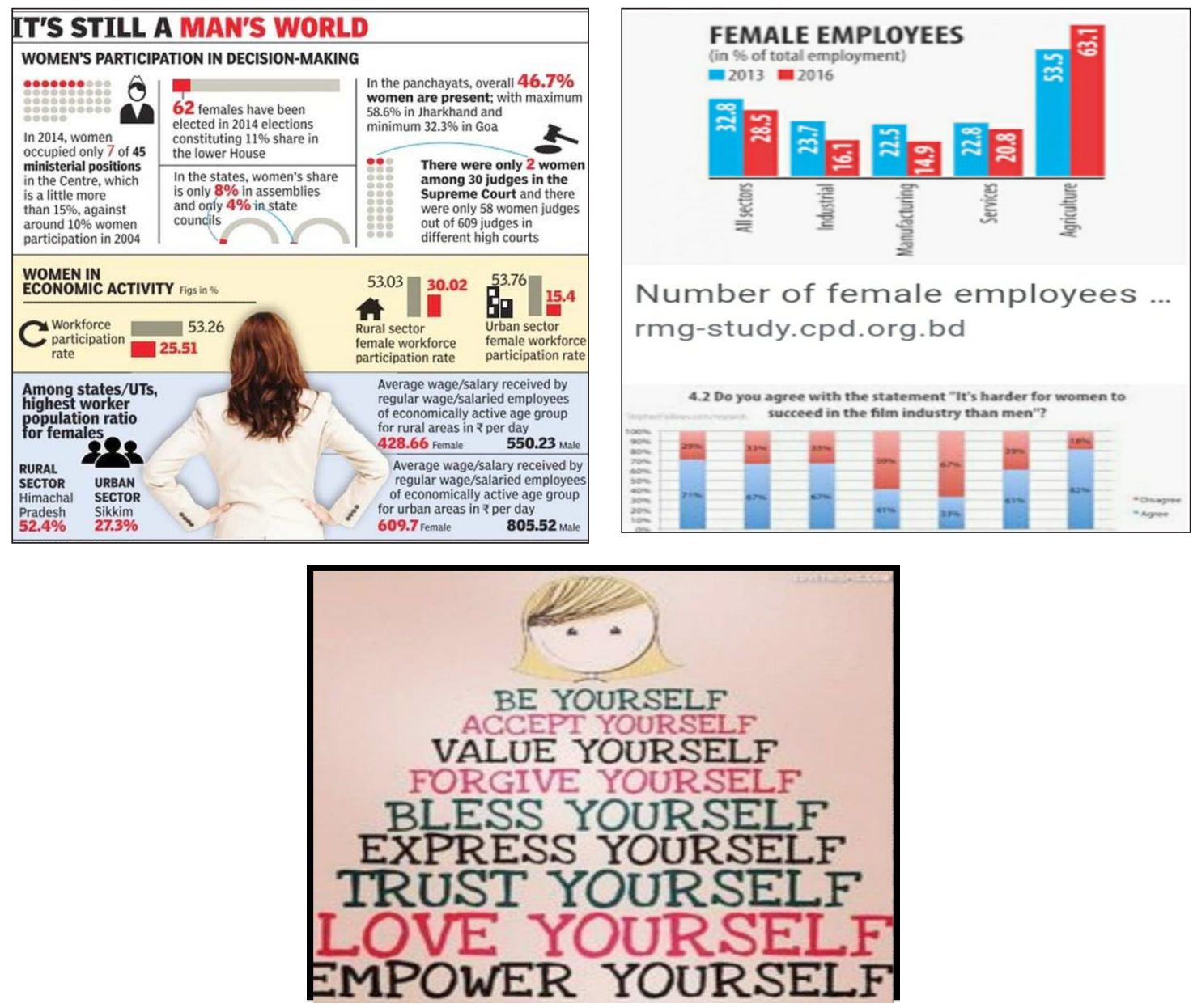

Fig. 1 
C Mehta

\section{Ways to empower women}

1. Changes in women's mobility and social interaction.

2. Changes in women's labour patterns.

3. Changes in women's access to and control over resources.

4. Changes in women's control over decision-making.

\section{REFERENCES}

1. Azeez, A. 1909. Development Programmers for weaker Section. Jaipur Publication, Jaipur.

2. Bhuyan, D. "Empowerment of Indian Women : A Challenge of $21^{\text {st }}$ Century". Social Sciences International Journal, 3(1).

3. Goel, A. 2004. Violence and Protective Measures for women development and empowerment. New Delhi, Deep and Deep, pp. 392.

4. Hazarika, D. 2015. Women Empowerment in India : A Brief Discussion. International Journal of Educational Administration, 1(3): 199-22.

5. Karl, M.. 2002. Women and Empowerment : Participation and Decision-making, London : Zed books, pp. 200.

6. Narrain, A. 2014. 'Sexual Violence and the Death Penalty', Economic and Political Weekly, 49(3): 38-41.

7. National Crime Records Bureau, Crime in India 2017-18, New Delhi.

8. Vinze, Medha Dubashi. 1981. “Women Empowerment in India : A Socio Economic Study of Delhi”, Mittal Publication, Delhi. 